\title{
PMDN, PMA and Labor Factors as the Indicators of the Success of Development in Province of Maluku: An Application of New Growth Theory
}

\author{
Ohorella Hasna ${ }^{1}$ \\ ${ }^{1}$ Faculty of Economics, Darussalam University, Ambon, Indonesia \\ Correspondence: Ohorella Hasna, Faculty of Economics, Darussalam University, Ambon, Indonesia. E-mail: \\ yundaqu@yahoo.co.id
}

Received: December 24, 2013

Accepted: October 2, 2014

Online Published: January 4, 2015

doi:10.5430/rwe.v6n1p58

URL: http://dx.doi.org/10.5430/rwe.v6n1p58

\begin{abstract}
The main purposes of the research are to analyze: (i) the effect of technological progress (A), capital by proxy of PMDN (domestic investment) and PMA (foreign investment), Labor (L) and human development (H) on economic growth, (ii) the effect of economic growth (Y) of public expenditures in health area (GEK) and of public expenditure in educational area (GEP) on human development, and (iii) the effect of health index (INKES), education index (INPDDK), and purchasing power index (INDB) on the productivity of labor in the Province of Maluku.

The method used in this research was an explanatory method and the type of research was verificative. The data used was panel data with a secondary data type consisting of time series data for 2004-2010 and cross-section in 8 (eight) regencies/municipalities. The method of parameter estimation was by using a Two Stage Least Square (TSLS) method for economic growth and human development equation as a simultaneous equation and productivity equation as a single equation, each with Fixed Effect Model (FEM).

The research results showed that (i) Technological progress, capitals by proxy of PMDN and PMA, labor, and human development have a positive and significant effect on economic growth, (ii) Economic growth has a positive and insignificant effect, whereas public expenditures in health and educational areas have a positive and significant effect, on human development, and (iii) health index has a positive and significant effect, and educational and purchasing power indexes have a positive and insignificant effect, on the productivity of labor, whereas purchasing power index has a positive effect on the productivity of labor in the Province of Maluku.
\end{abstract}

Keywords: PMDN, PMA AND LABOR, Two Stage Least Square (TSLS) and Fixed Effect Model (FEM)

\section{Introduction}

Development in wide perspective can bee seen as a multi-dimensional process which cover many basic changes of social structure, people's behavior and national institutions, beside to catch for economical growth acceleration, handling the unbalancing of income and poverty reduction (Todaro:2003). One indicator of the development progress is ecoomic growth, this indicator is basically used to measure prosperity of a country to increase its output faster than the level of population growth.

When economic growth become a main goal in performing economic development, then the focus of attention has directed to spur on high economic growth. Eventhough a high economic growth is only one of indicator to assess the success of economic growth, which is fit to the new paradigm of development that economy growth is still a necessary requirement but insufficient to development process (Hakim Abdul 2004). Economic growth is only recording increases in service and stuffs production, while the develompent itself has wider dimension than the increasing of economic growth (Kuncoro, 2008). It means that, the economic growth is no longer hold on GNP as the target of development, but more focus quality of development process.

Technological progress is part of a very important production activity. Because of the existence of the technological progress, capital and labor productivity can be more enhanced if only compared with the existence of capital and labor itselves. Measurement of Technological progress in economic development is not an easy problem. It can be seen from some aspects such as: management, the level of education, the application of new techniques, and etc. In Neo-classic 
Theory has pointed out that to establish economic performance of a nation, it needs capital accumulation A developing country is more need investment especially foreign investment because generally it has low level of domestic savings (Sadli, 2004).

Kobrin (2007) said that the investment especially foreign investment could and did play role as a transfer media of resources need like, technology, managerial capabilities, export lines, and capitals from industrial countries to developing countries and because of that, the investment will enhance the productivity and relevant to economic growth.

Role of foreign capital in the development by economic experts (Chenery and Carter, 1973), contended that the source of external fund (foreign capital) can be used by developing countries as a base to accelerate investment and economic growth, and the increasing economic growth followed by production structural changes and trade and foreign capital are also playing an important role in fund mobilization and even structural transformation. In this way, investment has become a keyword to determine the speed of economic growth, since beside it can encourage the raise of output significantly and automatically increase the demand of input, so at its turn it can excalate work opportunities and social welfare as consequences of income increasing accepted by the society.

New Growth Theory (Modern Endogen Theory) as the last development about economic growth, has attempted to explain the level of technological progress, which in Solow Model called Exogen variable. Endogenous growth, viewed capital return is constant in long term. The new growth theory built a more sophisticated model to explain the evolution of technology which this evolution has become an agent of economic movement. The key of theory difference between neoclassical and new growth theory is focused on aggregate return of capital and the implication to long term economic growth.

According to Todaro (2003), there are three main factors of economic growth in each country. These factors are (1) accumulation of capital, that covering all forms and types of new investments planting on the ground, physical equipments and capital or human resources (2) population growth which is able to multiply numbers of work force and (3) technological progress.

This is analogous with the experiments of new industrial countries like South Korea, Taiwan and developed industrial countries like France, Germany, United Kingdom and United States. It showed that the growth they have achieved is sourced from population growth, supported by human resources especially qualified labor. By this experience, then many developing countries include Indonesia has emphasized their human resources development especially labors and technology abilities to achieve growth objectives and economic development.

Human development according to UNDP (1990) can be defined as a process to magnify the choose for the population/human (a process of enlarging people's). Base on definition of UNDP that the point is on the human development in wide mean and it is not only for economic development. So, population growth in determining the goal of development and to analysis the choose to reach for it.

A reason why population/men growth should have an extra attention and very important to Maluku, because: first, that Maluku progress is relativelly successful by a high economic growth indicator but it still inadequate to decrease the socio-economic gap and powerty. Second, Maluku has high income, but it not quietly enough to diminish social problems, such as: drug abusement, alcohol, bummers, and ets. Third, some other areas have low incomes but are able to achieve a high level of human development since these areas can use all of their resources to develop their human base abilities.

Forewords, many writers who have been doing researches towards human development that relevant to economic growth. Some of them are the research of Ranis \& Ramirez (1998) with cross-country data (1970-1992). They have founded that there is strongly positive relationship between human development and economic growth. Beside, the government expenses to social sector have proved playing important role as a connector that determine the relationship strength between economic growth and human development.

showed that the rank decrease from 107 in the year of 2007, the quality of Indonesia's human development especially in education and healthy was not better than the years before. Then in 2010 UNDP released, Indonesia's IPM between 1980 until 2010 has raised 1,4 percent. With this velocity, Indonesia was on 108 of 169 countries in the world.

If explained more, we can said that human development is about the creation of environment where human can optimally develop their potential and continue their life productively and creatively according to their need and interest. Human is a real wealthy of a nation. Because of that, human development is relevant to the expansion of human's choose to walk on their valuable life. And by that, Generally, Indonesia's Human Development Index, if seen from Indonesia's human quality is still low, compared with human quality of other countriesin the world. According to the 
report of Human Development Index (IPM), released by United Nation Development Program (UNDP, 2009), Indonesia was in the rank of-111, far below other ASEAN countries. This Indonesia's IPM position human development is not only economic growth but also become the most important objective to expand human choose in their life. (Sudhir Anand and Amartya Sen, 2000).

According to the report which has made on an agreement among UNDP, BPS and Bappenas (2004), after the crisis IPM number in all over the province in Indonesia is seem to decrease. It means that generally, there is life quality degradation of Indonesian people. Base on background of the research, it shows that quality of human resources is very important to investigate and observed to become a deep study for local government especially in Province of Maluku. So, the writer has interesred to make research on this phenomena with tittle: PMDN, PMA and Labor Factors as the Indicators of the Success of Development in Province of Maluku: An Aplication of New Growth Theory.

This research is aimed to reveal and analyze the linkages between human development and economic growth to increase productivity in Maluku during 2004-2010. While the goal of the research are to:

1. Analyze the impact of technological progress, capital and labor factors and human development to economic growth in Province of Maluku during 2004-2010.

2. Analyze the impact of economic development, Government spendings in field of healthy and education towards human development in Province of Maluku during 2004-2010.

3. Analyze impact of health index, education index, and purchasing power index towards the increasing of labor productivity in Province of Maluku during 2004-2010.

\section{Literature Review}

\subsection{Economic Growth Theory}

Economic growth is one of the key indicators in analyzing economic development of a country. Growth and development are not identical. Economic growth is one of the requirements in developmental processes (Meier, 1989). It records only increases in the national productions of goods and services, whereas economic development has wider dimensions. In measuring a country's economic growth, economists agree to use gross domestic product (GDP). Moreover, basically economic growth can be seen from two sides, aggregate demand and aggregate supply.

\subsection{Endogenous Growth Theory (New Growth Theory)}

New growth theory is a new concept on both economic growth and development. It differs from Solow's model, in that it suggests that any changes in resources result in an accumulation of human and physical resources which in turn boosts workers' productivity. The model also supposes that the higher the educational level of workers, the larger the capital possessed. According to Harbinson, human resource is a basic capital of a country's wealth.

\subsection{Public Expenditure for Health Sector}

Health is a basic need for anyone. Without health, people can not contribute a high productivity to their country. A country's economic activities may be accomplished well if its individual citizens' health is secured. Related to human capital theory, human capital plays a significant role, even more important than technological factor in spurring on economic growth.

Advanced countries generally pay attention to their health budget because they believe that the advancement of a country heavily depends on that of its people health, considering that health is a key factor in enhancing the productivity of workers. Therefore, it is absolutely appropriate for public policies to pay more attention on health expenditure.

\subsection{Public Expenditure for Education Sector}

The currently developing economic growth theory is based on the productive capacity of human forces in developmental processes, also called investment in human capital. It means that enhancing people capacities become the most efficient basis in implementing development in any area.

An assumption on which the human capital theory is based is that formal education is a predominant factor in generating communities of high productivity. However, the performance of education has not yet been a pride for the education-seeking citizens due to the minimum interest of the government. According to Literacy Rate (2007), Indonesia's literacy level was only $90.4 \%$. That is, there were still around $10 \%$ of our population who cannot read, being illiterate. 


\subsection{Measuring Labor's Productivity}

Labor's productivity is one of a company's performance indicators. Increases in the working productivity can only be brought about by persons (Siagian, 2002). Therefore, labor is a main factor in measuring productivity. There are two reasons: first, because the costs incurred to labor as the largest part of product and service costs, and second, due to inputs to other factors. According to Lyncoln Arsyd (1999), labor's productivity can be measured by calculating the value-added of a region, i.e., Gross Regional Domestic Product (GRDP) and total labors. The productivity of labor is total products divided the total workers who are working for a certain time unit.

\subsection{Result of Empirical Study}

Many researches relating to economic growth-affecting factors have been conducted by earlier researchers, domestically and abroad. Some earlier researches or studies on physical capital, labor, human capital, labor productivity, and economic growth include among others:

Oluwatubi, Stephen O \& Ogunrinola I. Oluranti (2011). Their result reveals that there was a long term relationship between the variables applied to develop human capital (health and education) and economic growth in Nigeria. Physical capital (K) and public expenditure for humans (RE) correlated positively with output level (real GDP).

The study provides empirical evidence on the impact of FDI in both direct and indirect ways on the reduction of poverty in surveyed provinces and cities in Vietnam from the period from 1993 to 2002. Panel data analysis is used in the form of two regressions, which is represented in the growth model and poverty model in the paper, and the findings of the regressions are discussed. The major findings derived from the study are:

a) The inflows of FDI in a province are found to have a significant and positive effect on the economic growth.

b) The economic growth at the province level is found to have a positive and significant impact on the reduction of poverty.

c) The inflows of FDI have a directly and strongly positive and significant impact on the poverty reduction in a province.

Ishola Rufus \& Felix A. Adidu (2008). Their result reveals that the development of human capital is a crucial determinant in the growing process of a country, including among others:

a) Better educated populations would secure the education and health of their children, hence enhancing life quality and GNP per capita.

b) More innovative and more adaptive to technologies, thus improving both efficiency of physical capital and productivity of labors.

c) Human capital investment simultaneously would strongly and positively affect economic growth.

\section{Human Development Index Analysis and Influencing Factors in Province of Papua.}

The achievement of economy development in a territory is affected by human development process. This achievement cannot be detached from how qualified is human resources in a territory. The indicator to measure the human quality in a territory is the Human Development Index/Indeks Pembangunan Manusia (IPM).

This analysis provides the Gross Regional Domestic Product. Government expenses according to educational function, poverty ratio toward population, population ratio toward number of doctors, population ratio toward number of midwives, population ratio toward number of nurses, High school student ratio toward number of teachers, they are all affected the IPM, while the Elementary student ratio toward number of teachers, Junior high student ratio toward number of teachers, have no impact to IPM in Province of Papua. Population ratio toward number of nurses and population ratio toward number of midwives have positive impact to IPM, This is insufficient with the former study because some educational and health facilities in Province of Papua are inadequate for the population. So, to increase the IPM in the Province of Papua, the government should pay more attention to the facilities and infrastructures on educational and health sectors such as: increase the number of educational personnel, build Public Health Care Center (Puskesmas), increase medical personnel (doctor, midwife, nurse) in every sub district in Province of Papua.

Elia Radyanto and Insukindro (1995) in research Analysis of Factors Affecting Private Investment in Maluku. The research aims to analyze the effect of the regional Gross Domestic Product, the average interest rate and laborforce, as we asthe 1st june 1983 Monetery Policy on private invesment (Under thePMA and PMDN). 
The research findings indicate that, in shor and long terms, the Regional Gross Domestic Product can account for the positive varmation of private investment in Maluku, where as the average interest rate cannot. Different from the two variables above, labor force can only account for the variation of investment has indicated a positive development.

According to, Ali Tutupoho (2013): this research is aimed to know the impact of government investment, private investment, and quality of labor toward economy growth in District/City in Province of Maluku. Estimation method used is regression of panel data by Fixed Effect Approach, during 2002 - 2007. The result shows that the three dependent variables, are government investment ratio (public service), private investment ratio (PMA and PMDN), and quality of the labor (junior and senior high gradiates), are significantly and positively (partially and simultaneously), affected economy growth in district/city in Province of Maluku.

Ohorella Hasna (2013). The research result suggests that economic growth was positively and significantly affected by technology, PMDN, PMA, labor, and human development. Meanwhile, in the second model, economic growth affected insignificantly human development, due to the low capital labor ration (the low level of complementary investment in human capital (education), infrastructure or research and development (R \& D)). In the third model, the labors' productivity, the independent variables of which were INKES and INDB, was also insignificant, resulting from the low index of health (INKES). Malnutrition causes people unable to work, an impact of which was low income and people' decreased purchasing power. Based on the research result, it is suggested that human development should precede economic growth to produce a virtuous developmental cycle.

\section{Method}

\subsection{Research Method}

Methods to be used in this research is verificatively Eksplanatory research. This eksplanatory method is relevant to be used for social research to see, measure and test causality relationships among many variables based on data gathered to obtain the meaning and problems implication to be solved systematically, actually and accurately. Characteristic of this research ini is verificative that is research for the linkages and impacts among independen variables towards dependen variables. In this relationship, then it has done statistical and economtrical tests to obtain conclutions of the research.

While descriptive research is used to find out and understand the phenomena in better definition gathering. This is meant to describe emphirical phenomena and interpretations to get more concrete and factual about variables that effects economic growth. This economic growth consists of technological progress factor, capital proxied with Domestic investment/Domestic investment (PMDN), Foreign Capital Investment/Penanaman Modal Asing (PMA), Labor dan Human Development (H), and also human development which is consists of Economic Growth factors, Government spendings for healthy, education, and productivity which is consist of healthy index, education index, and purchasing power index in each regencies/city in Province of Maluku during 2004-2010.

\subsection{Data Type and Source}

The data type used in the current research was secondary data in a form of panel data (pooled data), which was a combination of time series data, that is, a collection of relevant data from 2004-2010, and inter-space (cross-section) data, i.e., 8 districts/municipalities in Maluku Province. The main data was derived from regional and national Statistical Center Agency (BPS), United Nation Development Programme (UNDP) in some publications, National Development Planning Agency (BAPPENAS), Regional Development Planning Agency (BAPPEDA), Investment Coordination Agency (BKPM), Regional Investment Agency (BPMD) of Maluku, and other relevant institutions in addition to the journals and research results relevant to the investigated subject.

Because each of the different data sources applied different data collection and computation, the data processing applied was adjusted, given that a diversity in the research data was highly needed, or in other words the data collected was reprocessed such that it fitted to the current research's need.

\section{Model of Analysis}

In this research, model to be used is a simultaneous equation model. This model is a development from regression model. In a simultaneous equation between explaining variable and dependent variable, there is an interdependency or two way causality, which make differency between controlled variable explained variable become doubted (Gujarati, 2003). If the estimation has done by ordinary least square (OLS) regression then the results will be inconsistent, from the possibility of correlation between explaining variable and error element. Because of this consideration, to avoid inconsistencies of regression results then the test steps should fit to simultaneous equation using requirements shoul be done. 
The model for this research is economic growth with human development as endogen variable and the predictor variables are technological progress, capital proxied with PMDN and PMA, labor, Government spendings to healthy and education.

By this condition, model specification for this research is simultaneous equation model consists of two structural equations, that is:

$$
\begin{gathered}
\mathrm{LY}_{i t}=\alpha_{0}+\alpha_{1} A_{i t}+\alpha_{2} L P M D N_{i t}+\alpha_{3} L P M A_{i t}+\alpha_{4} L L_{i t}+\alpha_{5} L H+e_{1} \\
L H_{i t}=\beta_{0}+\beta_{1} L Y_{i t}+\beta_{2} L G E K_{i t}+\beta_{3} L G E P_{i t}+e_{2}
\end{gathered}
$$

Where:

$\begin{array}{ll}\mathrm{Y}_{\mathrm{it}} & =\text { Economic Growth } / \text { PDRB } \\ \mathrm{A}_{\mathrm{it}} & =\text { Technological Progress } \\ \mathrm{PMDN}_{\mathrm{it}} & =\text { Domestic investment } \\ \mathrm{PMA}_{\mathrm{it}} & =\text { Foreign Capital Investment } \\ \mathrm{L}_{\mathrm{it}} & =\text { Labor } \\ \mathrm{H}_{\mathrm{it}} & =\text { Human development } \\ \mathrm{GEK}_{\mathrm{it}} & =\text { Government spendings for Healthy } \\ \mathrm{GEP}_{\text {it }} & =\text { Government spendings for education } \\ \varepsilon_{\text {it, }}, \mathrm{v}_{\mathrm{it}} & =\text { error term } \\ \beta_{0}, \partial_{0} & =\text { Parameter, } \mathrm{i}=1,2,3 \ldots \ldots \ldots . . . \mathrm{n} \\ \mathrm{L} & \\ \mathrm{I} & =\text { Area } \mathrm{i}(\mathrm{i}=1,2, \ldots \ldots \ldots . .11) \\ \mathrm{T} & =\text { Year/period of } \mathrm{t}(\mathrm{t}=2004-2010)\end{array}$

Beside those two simultaneous equations, this research has also use a regression model by non simultaneous equation to analyze quantitative informations (the data can be measured, tested and informed in form of equation, table, etc).

Labor productivity with human development proxied by healthy index, education index and purchasing power index in the research is functionally as follows:

$$
L P=F(I N K E S, I N P D D K, I N D B)
$$

From the equation function (4.3) above, it can made to a multiply linier regression equation by adding error term $\left({ }^{\varepsilon}\right.$ ). The complete model can be seen as the equation below:

$$
L P=\delta_{0}+\delta_{1} I N K E S+\delta_{2} I N P D D K+\delta_{3} I N D B+\forall
$$

$\delta_{1>0 ;} \delta_{2>0 ;} \delta_{3>0 ;} \delta_{4>0 ;}$ Cateris Paribus

Where:

$\begin{array}{ll}\text { LP } & =\text { Labor Productivity } \\ \text { INKES } & =\text { Healthy Index } \\ \text { INPDDK } & =\text { Education Index } \\ \text { INDB } & =\text { Purchasing power index }\end{array}$




$$
\begin{array}{ll}
\delta & =\text { parameter }(\mathrm{n}=1,2,3,) \\
\forall & =\text { error term }
\end{array}
$$

From the calculation result shows that the equation is in over-identified condition, then it will use Two Stage Least Square (TSLS) method, since this method is better then OLS (Ordinary Least Square) method if apllicated to over-identified and exactly-identified simultaneous equation.

\section{Results and Analysis}

\subsection{Estimation Results of Economic Growth Model}

As results of the former test where simultanity between level of Economic Growth and level of human development, then to estimate Economic Growth Model we determine to use simultaneous equation by estimation method. This method uses two stage least square (TSLS), while in forming the model we use fixed effect model approach according to conclusion obtained from Hausman Spesificaton Test.

Empirical method from estimation results of Technological Progress impact level (A), domestic investment (PMDN), foreign capital investment (PMA), numbers of Labor (L), and human development $(\mathrm{H})$ to the level of Economic Growth in Province of Maluku during 2004-2010 is as follows;

Tabel 1. Estimation results of economic growth model

\begin{tabular}{ccccr}
\hline \hline Variable & Coefficient & Std. Error & t-Statistic & Prob. \\
\hline \hline C & 0.532223 & 1.394195 & 0.381742 & 0.7050 \\
A? & 0.002304 & 0.000127 & 18.12754 & 0.0000 \\
LNPMDN? & 0.072127 & 0.023310 & 3.094247 & 0.0039 \\
LNPMA? & 0.010012 & 0.004464 & 2.242589 & 0.0314 \\
LNL? & 0.253131 & 0.042959 & 5.892357 & 0.0000 \\
LNH? & 2.016673 & 0.441912 & 4.563514 & 0.0001 \\
\hline \hline R-squared & 0.997997 & Mean dependent var & & 20.69309 \\
Adjusted R-squared & 0.997310 & S.D. dependent var & & 8.109095 \\
S.E. of regression & 0.046881 & Sum squared resid & & 0.076923 \\
F-statistic & 1453.301 & Durbin-Watson stat & & 1.369421 \\
Prob(F-statistic) & 0.000000 & & \\
\hline \hline
\end{tabular}

Dependen Variabel: LPDRB?

$$
\operatorname{LnPDRB}=0.532+0.002 \mathrm{~A}+0.072 \operatorname{LnPMDN}+0.010 \mathrm{LnPMA}+0.253 \mathrm{LnL}+2.017 \mathrm{LnH}
$$

From the above model, it can be seen that level of Technological Progress (A), domestic investment (PMDN), foreign capital investment (PMA) and Labor (L) and human development $(\mathrm{H})$ have positive impact to Economic Growth in Province of Maluku.

\subsection{Analysis of Economic Growth Model}

\subsubsection{Interpretation to the Constant of Economic Growth Model}

By considering results of the test towards the Economic Growth Model estimation results of Province of Maluku in Equation 1, where it has the Constant (C) positive value of 0,532. This indicates that if the whole independent variable are equal to zero, then PDRB in Province of Maluku will have the same value as the Constant. This is reasonable since impacts of all independent variable such as: Technological Progress (A), Investment (PMDN and PMA), Labor (L), and Human development $(\mathrm{H})$ are important factors to Economic Growth in Province of Maluku. But, because the estimation model uses data panel with Fixed Effect approach so that interpretation of Constant coefficient for regencies/city is different one from the other. There is a negative and also positive sign. Some regencies/cities which 
have positive sign constant are: MTB, Malteng, and Ambon. This has consequence to the smaller constant value of those regencies/cities. This indicates that if there is none of independent variables, it will impacts to the relatively low Economic Growth. This is reasonable since an area with positive sign constant has different Economic Growth. On the contrary, the area with negative sign constant still have no endowment factors as complete as those with positive constant, also the remote geographical position that made these areas need additional efforts to be reached for. It is natural if Technological Progress (A), Domestics Capital Investment (PMDN), Foreign Capital Investment (PMA), Labor (L) and Human development (H) are the very important factors for Economic Growth in the area.

\subsubsection{Coefficient of Economic Growth Model}

\subsubsection{Impact of Technological Progress to Economic Growth}

Considering the test results to estimation results for coefficient $\mathrm{A}$, it has positive sign eventhough the number or the value is very small. This indicates that if Technological Progress (A) increases/more modern, so it will impact to the increase of Economic Growth. With the coefficient of 0,002, means that if Technological Progress increases $1 \%$, then Economic Growth for Province of Maluku will increas as high as the coefficient value or 0,002 \%. The small impact of Technological Progress enhancement to Economic Growth, can be interpreted because Technological Progress has pattern/behave as chi-squares, which means starts from a high marginal technical progress (MTP) then ended with the low MTP. If this related to the condition in Province of Maluku where Economic Growth is more dominated by the Agriculture sector, Trade Sector, Hotel and Restaurats and Service Sector, which have different dinamics so it needs different Technological Progress either.

Agriculture sector has the law of deminishing return to scale characteristic and affected by natural cycle so the Technological Progress in this sector will difficult to accelerate for quick yielding, compared with Trade Sector, Hotel and Restaurants. From the analysis results can be found that contribution of agricultural sector to PDRB of Maluku during the last five years is around $35-40 \%$, so that it is reasonable if Economic Growth of Maluku is a little bit slower than the other area, and dominated by secondary and tertiary sectors. Beside the reasons above, Province of Maluku which consists of islands with high need of quick, reliable, and economic transportation, such transportation requirements is needed to distribute products, people and services related one to another place/island, to form supplay chains relationship. Finally, aggregately will increas the Economic Growth of Province of Maluku. These transportation modes will be fast and efficient if it applies more modern technology, such as fast ship, so the fish catch product wil be delivered faster to the market or customer in high quality of product so that it can maintain a high price of product. So does the other commodities which also need fast distribution process like agricultural products. Considering the urgency of Technological Progress in enhancing Economic Growth in Province of Maluku, then its existence is relly strategic. This fact has also been supported by the results of significancy test through t-Test with the value of $\mathrm{t}_{\text {count }}$ is $18,128>\mathrm{t}_{\text {table }}$ on the $\alpha$ value $=5 \%$, which means that the test results is significant $/ \mathrm{real}$.

The Existence of strategic Technological Progress in Maluku can be maintained by the facts that the Government of Maluku has cooperate with some universities in scientific and technological researches especially in processing technology of marine products, land and sea transportations, Information technology. Moreover, the Government of Maluku through APBD budgeted the web-based information system development to create cyber city. Gradually, this idea has already applicated where some governmental office have already use the internet.

\subsubsection{The Impact of Investment (PMDN and PMA) towards Economic Growth}

Investment factor is a very important thing in increasing Economic Growth in Province of Maluku. This is strengthened by the regression results on domestic investment (PMDN) and foreign investment (PMA) with positive sign. This indicates that if domestic investment (PMDN) dan foreign investment (PMA) increases 1\% then Economic Growth in Province of Maluku will also increases as high as the coefficient value or $0.072 \%$ and $0.010 \%$. The progress of PMDN and PMA in Province of Maluku, is not delighting enough, since during the research, investment realization wasn't appropriate the target. This is allegedly as the affect of condition in Maluku which was affected by social conflict, so thus the investors reluctant to invest in Maluku. Some former researches suggested that the investor will invest their money if they felt safe and benefit of the investment. In fact, for some investments, Maluku was very profitable such as the processing of marine and farming products. This is supported by the nature of Maluku with rich of fishery potential, and its suitable soil for oil palm, etc. For the access to foreign market/export it has oriented to the market of Australia, Phillipines and Japan.

\subsubsection{The Impact of Labor toward Economic Growth}

Labor is one important factor which impacts the Economic Growth. The increased number of Labor in productive economical activities will encourage the production capacity to increase the demand of products and services. Base on 
the estimation results, labor coefficient has positive relationship to Economic Growth, where its coefficient value is 0.253. this indicates that if labor increases 1 percent, then it wull increase Economic Growth as high as the coefficient value or $0.253 \%$.

Spme literatures like Cobb-Douglas Model, Sollow Model, etc, have descripted that the role of labor as a production factor is very important. This is in accordance with the condition in Maluku, where the Economic Growth in Maluku mostly because of labor factor, considering many productive economic sector have implemented intensive labor pattern, and beside the productivity of their labor is relatively good. Maluku as the destination of labor migration especially in East Indonesia, and its a the place where labor from many other areas were collected in, has affected to competition and motivation of the labor to enhance their achievements and productivity. Those who has inadequate to compete will be eliminated and get out of Maluku and they will compete at the level of technical skill. They will keep working and decrease their leisure to survive. This condition is supported by significance test with $\mathrm{t}$ test $\left(\mathrm{t}_{\text {count }}\right)=5,892$ and probability value of 0,000 . This condition is statistically significant/real.

\subsubsection{Impact of Human development towards Economic Growth}

By considering the regression result, the affect of human development $(\mathrm{H})$ toward Economic Growth (PDRB) has positive coefficient. This indicates that the increase of human development will increase Economic Growth of Maluku. This increase of human development through health, education, and purchasing power enhancement, will increase the human quality, to be more stronger, smarter, and more productive. This coefficient value of 2.017 means that every increasing $1 \%$ of human development in Maluku will increase Economic Growth of $2.017 \%$. It seems that independent variable of human development $(\mathrm{H})$ has the highest coefficient value, and so does if viewed from the elasticity between human development (H) and Economic Growth (PDRB). Then for Maluku, it has In-Elastic characteristic where the changing percentage of $\mathrm{H}$ will has affected to a relatively small impact to Economic Growth percentation. This is reasonable since human development $(\mathrm{H})$ has passing through a long process, can not be directly perceived and abstract (Non-Deterministic). Even though, the human development is very important in long term. Maluku included in The Center of National Activity/Pusat Kegiatan Nasional (PKN) and Ambon is as a Center of Regional Activity/Pusat Kegiatan Wilayah (PKW), emphasized to be able to become the real "The Activity Center/Pusat Kegiatan" through efforts of human resource quality enhancement. The strategy of human development through enhancement of health, education and purchasing power, and also the policy tools, is urgently need to realize the efforts.

\subsection{Estimation Results of Human Development Model}

Estimation results of the impact of Economic Growth level (Y), Government spendings for health (GEK), and Government spendings for education (GEP) to the level of human development in Province of Maluku during 2004-2010 are as follow :

Table 2. Estimation results of human development model

\begin{tabular}{crrrr}
\hline \hline Variable & Coefficient & Std. Error & t-Statistic & Prob. \\
\hline \hline C & 3.965061 & 0.075693 & 52.38338 & 0.0000 \\
LNPDRB? & 0.003700 & 0.006544 & 0.565488 & 0.5746 \\
LNGEK? & 0.014015 & 0.005212 & 2.688918 & 0.0100 \\
LNGEP? & 0.007750 & 0.004497 & 1.723452 & 0.0917 \\
\hline \hline & 0.943300 & Mean dependent var & 6.323120 \\
R-squared & 0.930699 & S.D. dependent var & 3.471837 \\
Adjusted R-squared & 0.017412 & Sum squared resid & 0.013643 \\
S.E. of regression & 74.86450 & Durbin-Watson stat & 0.747131 \\
F-statistic & 0.000000 & & \\
Prob(F-statistic) & & & \\
\hline \hline
\end{tabular}

Dependent Variable: LNH?

$$
L n H=3.965+0.004 \operatorname{LnPDRB}+0.014 \operatorname{LnGEK}+0.008 \operatorname{LnGEP}
$$


In the model above, it can be seen that the level of Economic Growth (PDRB), Government spendings for health sector (GEK) and Government spendings for education sector (GEP) give positive contribution to the level of human development in Maluku.

\subsection{Discussion on Human Development Model}

It is the same as the discussion on estimation results of Economic Growth Model, then the discussion on estimation results of Human Development Model is also devided into to parts, from intercept parameter and coefficient parameter.

\subsubsection{Intercept of Human Development Model}

Considering the test results to estimation results of Human Development Model (H) in Province of Maluku at Equation 2 , where it has positive constant value (C) or 3.965. This shows that if all independent variable are equal to zero, than the human development will be as high as the constant value.

The different intercept among regencies/cities, shows the quality differencies of human resources in each area. This is caused by the limited accessibility to qualified health service to poor and disadvantaged community, the community in remote area, borderlands and outer islands. This is caused by distance constraint, cost and the condition of health service facilities like Puskesmas and the networks which are not completely reached by the community. It has caused by the less attention of local government to health and education facilities and this can be seen from the size of Government spendings for the health sector and education sector in APBD of each area is still far from the expected.

\subsubsection{Coefficient of Human Development Model}

\subsubsection{The Impact of Economic Growth toward Human development}

If it's viewed from the coefficient of estimation results of Economic Growth model, that variable coefficient of Economic Growth is positive through human development. With coefficient of 0.004, means that if Economic Growth increases 1 percent, then it will increase human development coefficient value as high as the coefficient value of 0.004 percent.

The small coefficient number of Economic Growth to the enhancement of human development in Province of Maluku, shows that the increasing of society income is not in accordance with the increasing of purchasing power. Beside that, the high or low level of Economic Growth could also affected by variable A, PMDN, PMA, L and H, which according to Solow, Economic Growth depends on the development of production factors.

\subsubsection{Impact of Government Spendings in Health Sector and Education Sector towards Human Development}

Another factor that also very important to human development is Government spendings in health sector and education sector. Government spendings in these sectors are real form of the government responsibility to provide public stuffs. If the local government wants to seek for the increase of human development index in Province of Maluku, then one supporting factor to be executed by the government is increse the proportion or seek for the increasing of funding allocation of APBD in health sector and education sector, because it has indicated as significantly impact. Because if funding allocation of APBD for government spendings in health and education sectors is bigger then it will give a good impact to the quality of human resource in each area.

Thus, it should be that the health and education of the community in each area should become focus of attention from the government in order to public service, since good health and education will become a good input for human development and potentially enough to reach for the expected level of community's prosperity. Higher government spendings for health and education sectors will become a stimulator which will give a better impacts to the increase of human development quality, moreover, if the less attention from the government in allocating a relatively small fund for health sector. Whereas until now, there are still many health programs such as: Community Health Insurance/Jaminan Kesehatan masyarakat, the Famili Planning Program/Program Keluarga berencana, generic drug subsidy, until free health care services are still need much more funding, moreover population that has been growing every year, has become a spesific burden to the government to provide health service in high number. It has been problem in public health service until today.

\subsection{Estimation Results of Labor Productivity Model}

Estimation results of multiply linier regression model to assess the impact of health index, education index, and purchasing power index of the community to the labor productivity, can be obtained from Table 3; 
Table 3. Estimation results of labor productivity model

\begin{tabular}{|c|c|c|c|c|}
\hline Variable & Coefficient & Std. Error & t-Statistic & Prob. \\
\hline $\mathrm{C}$ & -5.257943 & 2.997978 & -1.753830 & 0.0863 \\
\hline INKES? & 12.60331 & 3.649283 & 3.453638 & 0.0012 \\
\hline INPDDK? & 2.976615 & 2.216202 & 1.343115 & 0.1860 \\
\hline INDB? & 1.658427 & 1.403815 & 1.181371 & 0.2437 \\
\hline R-squared & 0.957510 & Mean dependent var & & 15.41329 \\
\hline Adjusted R-squared & 0.948067 & S.D. dependent var & & 10.47103 \\
\hline S.E. of regression & 0.613054 & Sum squared resid & & 16.91257 \\
\hline F-statistic & 101.4060 & Durbin-Watson stat & & 1.844508 \\
\hline Prob(F-statistic) & 0.000000 & & & \\
\hline
\end{tabular}

Dependent Variable: LP?

From the table below, the regression equation is as follow:

$$
L P=-5,258+12,603 \text { INKES }+2,977 \text { INPDDK }+1,658 I N D B
$$

\section{Discussion of Labor Productivity Model}

Enhancement of labor productivity essentially caused by the improvements in labor quality through more efficient education and training, and improvement in production techniques. This improvement in labor quality will encourage the labor appropriate to their interest and capability. Beside that, one way to actualize quilified human resources is through enhancing the public health degree where its indicators are mortality, morbidity, and nutrition status. Study results, Poverty Analysis, MDGs and National Health Policy/Kebijakan Kesehatan Nasional (Wiku Adisasmita,2008), the low degree of Indonesia's Health, are challenges for health sector and other relevant sectors to cooperatively participate in health development for the community by providing easy access to health services, giving qualified health services, and empowering the community to perform clean and health life style and to create a hygiene environment.

\subsubsection{Intercept of Labor Productivity Model}

Considering the test results to estimation results of Labor Productivity Model in Province of Maluku at Equation 4.3, where it has negative constant value (C) of -5.258 , it indicates that if all independent variables are equal to zero, then Labor Productivity will be as high as the constant value.

Base on the estimation results that the occur of coefficient differencies among regencies/cities indicates that there are quality differencies of human resources in each area, because of the differencies of public access to healt facilities in that regencies/cities, where the problem of health development is the limited access to qualified health service especially in poor populated area, population in disadvantage area, remote area, population in borderlands, and outer islands. Its also caused by distance constraint, cost and the condition of public health facilities such as Puskesmas and its networks which can not fully be reached by the public. The limited facilities of education and health as a consequence of the less attention from local government to education and health facilities. This can be seen from the high Government spendings for health sector and education sector to APBD of each area with less than 20 percent.

\subsubsection{Coefficient of Labor Productivity Model}

\subsubsection{The Impact of Healthy Index towards Labor Productivity}

Base on the estimation results, coefficient of Labor Productivity Model shows that coefficient of healthy index variable has positive and significant relationshop to labor productivity, where the coefficient value is 12.603 . This indicates that if healthy index variable increases 1 percent, it will also raise the productivity up to as high as the coefficient value or 12,603 percent. 
This estimation results is appropriate with our hypothesis from the former chapter, where the healthy index has positive impact to labor productivity. According to World Health Organization (Komaruddin, 2003), healthy is a completly good condition physically, mentally, and socially, and is not only no disease, neither do about medical stuffs, but it's about social goal.

\subsubsection{The Impact of Education Index towards Labor Productivity}

According to estimation results, coefficient of Labor Productivity Model, indicates that coefficient of education index variable has positive relationship toward the labor productivity, where its coefficient value is 2.977 . This indicates that if education index variable increases 1 percent, it will also increase the productivity is as high as the coefficient value or 2,977 percent.

This estimation results is also appropriate with the hypothesis from former chapter, that education index has positive impact to the labor productivity. According to Tadjudin (2005), economic change effort as the impact of development activity is possibly happens since there is improvement in education sector. So for the condition of Maluku, we can said that its human resources has not reflect yet the income level, since it wan't able to develop it knowledge and skill of Maluku people. It causes the education is not significant to the productivity. In accordance with this, according to Hidayat (Tilaar,2000) said that an area will not be able to develop itself if it could not develop its knowledge and skill of the people and also couldn't utilize its resource potential optimally.

\subsubsection{The impact of Purchasibility towards Labor's Productiviy}

The level of social welfare can be measured through the size of expenses. Generally, ability of the society to purchase can give description to the level of society's welfare. Base on the model coefficient estimation results of Labor productivity, shows coefficient variable index of purchasibility has a positive relationship to the labor productivity, where coefficient value is 1.658 , this indicates that if index variable of purchasibility increase 1 percent, then it will pursue the level of productivity at the same value with the coefficient.

The estimation results is match with our hypothesis in the former chapter, that purchasing power index has positive impact towards labor productivity. According to Tadjudin (2005) the effort of economic changes as impact of development is possible to appear because of the improvement in education. So, it can be conclude that the human resource in Maluku hasn't been reflecting in the level of income, because it can't be able to develop knowledge and skills of community of Maluku. It means that if the low productivity of each labor, then the level of income is predicted to be low either. This condition will affected to the increse nor decrease of purchasing power of the community.

\section{Conclusion and Suggestion}

\subsection{Conclusion}

1. Economic Growth in regencies/cities in Province of Maluku are positively and significantly affected by technological progress, domestic investment, foreign investment, labor, and human development. This indicates that if all independent variables are increased, then it will affect to the economic growth.

2. Human development in regencies/cities in Province of Maluku is affected positively by economic growth, Government spendings in healthy sector and education sector. Economic growth according to estimation results is not significant. This means that if all independent variables is increased then human development will also be increased. This insignificance of economic growth impact to human development shows that small coefficient number of economic growth to human development enhancement in Province of Maluku indicates that enhancement of society's income is not in line with the enhancement of purchasing power. Beside that, the low or the high of economic growth has also affected by variable A, PMDN, PMA, L and H. According to Solow, the economic growth is depend on the development of production factors.

3. Labor productivity in regencies/cities in Province of Maluku has positively influenced by healthy index, education index and purchasing power index. According to estimation results, healthy index significantly is on confidence level of $95 \%$, while healthy index and purchasing power index is not significant. This means that if exogen variables has increased then the labor productivity will also increase. In addition to economic growth effort as an impact of development activity, it is possible to happen since there was an improvement in sector of education. So, for the condition in Maluku, we can said that its human resources hasn't been reflected in income level, because it wasn't able to develop the knowledge and skill of Maluku people. This causes the education and also purchasing power is not significant and affected to the labor productivity. 
Based on the research result, the writer concluded that the research contributes more strongly to regional development, particularly Maluku Province, as a solution in resolving any problems relating to the development of human resource quality than the earlier researches on public expenditures in health and education areas.

\subsection{Suggestion}

\subsubsection{Suggestion to Academic Development}

1. The Human Development Model established in this research has only three controlable variables that are economic growth, Government spendings in health sector and education sector. For model improvement, I suggest the future research to perform wider scope of research by adding other controlable variables which are importantly contribute to increase quality of human resources.

2. In Labor Productivity Model, beside IPM variables (healthy index, education index, and purchasing power index), there are some other variables that contribute to Labor productivity. This is caused by the estimation results saying that education index and purchasing power index are not significant to Labor productivity. It's been realised that until now, there is no IPM variable to be used into research variable especially the one that have impact to labor productivity in an area, so the results of the research will be a more interesting topic for the future research.

\subsubsection{Suggestion to Operational Policy}

1. Human development model for Economic Growth variable, according to estimation results is not significant. Because of that, to make Economic Growth has more impact towards human development, then there should be suggestions proposed by the writer among others; a) The development budget should exhibit alignments to sectors that especially touch the human development. b) Educational service and public health efforts are needed to increase, so that public access to health and educational services will become easier and affordable.

2. Quality of Maluku society, if associated with the development of resources, is still low. For that reason, we suggest the local government to more emphasize on the Policy that can support the human resource development through education and training. This education and training program should in accordance with the situation and condition of human resources in Maluku, so that in turn will bring direct impact to the increasing of community income and their purchasing power.

\section{Acknowledgement}

This article has been finished by the guidance of Promotors. I am grateful to Bapak Prof. H. Ahmadi Rilam, SE., MS as the Leader of Promotor Team, Ibu Prof. Dr. Hj. Sutyastie Soemitro Remi, SE., MS. As the member of the team and Bapak Kodrat Wibowo, SE., MA., Ph.D. as the member of Promotor Team. I sincerely grateful for spending their precious time and thoughts to guide me attentively. For those kindness and whole humility, I give my appreciation and thankful to The Promotor Team.

\section{References}

Abel, Bernanke, \& Heinemann Frank. (2010). Growth and Technological Progress. Macroeconomics (5th ed.). p.215.

Adisasmita Wiku. (2008). Analisis kemiskinan, MDGs dan Kebijakan Kesehatan Nasional: case study. Fakultas kesehatan Masyarakat, Universitas Indonesia.

Akpan, Patrick.L. (2009). Public Expenditure and Human Development in Nigeria.Faculty of Management Sciences. Cross River University Of Technology, Nigeria.

Alejandro Ramirez, Gustav Ranis, \& Frances Steward. (1998). Working Paper Number 18, Economic Growth and Human Development. QEH Working Paper Series-QEHWPS18.

Anand, S., \& Sen, A. (2000). Human Development Index: Methodology and measurement. Human Development Report Office Occasional Paper 12, UNDP, New York.

BAPPENAS and UNDP Indonesia, Indonesia Human Development Report. (2004). The Economics Democracy: Financing Human Development in Indonesia. Published Jointly by BPS-Statistic Indonesia.

BPS dan BAPPEDA Province of Maluku, (2010). Analisis Regional Income Province of Maluku Menurut Regencies/Kota dan Gugus Pulau tahun 2009.

BPS, BAPPENAS dan UNDP. (2001). Indonesia: Laporan Human development 2001. Menuju Konsensus Baru: Demokrasi dan Human development Indonesia, Jakarta. 
Dana Alokasi Khusus bidang pendidikan Per Tahun Provinsi Maluku Diakses dari www.tkp2edak.org/dataalokasibidangkab.asp?kdp=8100\&dkd=Dana\%20Alokasi\%20Khusus\&prv=Maluku\&bi $\mathrm{d}=$ Bidang $\% 20$

Gujarati, Damodar N. (2003). Basic Econometrics (4 ${ }^{\text {th }}$ ed.). International Edition, McGraw-Hill, New York.

Gujarati, Damodar N. (2003). Basic Econometrics. McGraw-Hill/Irwin, New York.

Mankiw G. Romer D., \& Weil David N. (1992). A Contribution to the Empirics of Economics Growth. Quarterly Journal of Economics, 107.

Nafzinger E. Wayne. (1997). The Economis of Developing Countries. A Simon \& Schuster Company, New Jersey.

Niringiye Aggrey. (2010). Effect of Human Capital on Labor Productivity in Subsahara African Manufacturing Firm. Paper to be Presented, Globalics Comference, Malaysia.

, Luvanda, E., \& Shitundu Joseph, (2010). Human Capital and Labor Productivity in East African Manufacturing Firms. Current Research Journal of Economic Theory, 48-54.

Oluwatobi Stephen O., \& Ogunrinola I. Oluranti. (2011). Government Expenditure On Human Capital Development: Implication for Economic Growth in Nigeria. Journal of Sustainable Development, 4(3), Juni.

Paolo Palazzi, \& Alessia Lauri. (1998). The Human Development Index: Suggested Corrections. Banca Nazionale del Lavoro Quarterly Review, 51, 193.

Pendidikan\&kdbid=DAK1 tanggal 15 Maret 2012.

Pindyck, S., Robert, \& Daniel L., Rubinfield. (1998). Econometrics Models and Economic Forecast (Fourth ed.). Singapore: McGraw-Hill, International Edition.

R. F. Engle, \& C.W.J. Granger. (1987). Co-integration and Error Correction. Representation, Estimation and Testing. Econometrica, 55.

Ranis, G., Steward, F., \& Ramirez, A. (2000a). Economic Growth an Human Development. World Development, 28(2), 197-219.

(2000b). Working Paper Number 32, Strategies for Success in Human Development. QEH Working Paper Series-QEHWPS32.

Ranis, G., Steward, F., Ramirez, A., \& Samman, E. (2005). Human Development: Beyond the HDI, Center Discussion, Paper 916, Economic Growth Center, Yale Univercity.

Romer, David. (1996). Advanced Macroeconomics (International Edition). McGraw-Hill Book Co, Singapore.

Samuelson, Paul, A., \& Nordhaus, William D. (2001). Economics (Seventeenth ed., International Edition). McGraw-Hill Companies, Inc.

Scott McDonald, \& Jennifer Roberts. (2002). Growth and Multiple Forms of Human Capital in an Augmented Solow Model: A Panel Data Investigation. Economic Letters, 74, 271-276.

Sihombing, A. Buyung. (2002). Studi Kependudukan dalam pembangunan. Jurnal Ekonomi PPS Unimed.

Todaro, Michael. (2000). Economic Development (Seventh ed.). Addison-Wesley Longman, London and New York Univercity.

United Nation Development Programme (UNDP). (2007). Human Development Report 2007/2008. New York: United Nations Development Programme.

United Nation Development Programme (UNDP). (2008). The state of human development. UNDP, New York (forthcoming in September).

Wooldridge, Jeffrey M. (2005). Introductory Econometrics. A Modern Approach. The MIT PRESS, Cambridge.

World Bank. (2005). World development indicators. CDROM. World Bank, Washington, DC.

Zhang, Amei. (1996). Economic Growth and Human Development in China. Occasional Paper No 28 Human Development Report. 